\title{
THESES
}

\section{CONTRIBUTION TO THE STUDY OF THE SPINAL CORD CHANGES DURING EXPERIMENTAL MODEL OF THE ACUTE SPINAL CORD INJURY (ABSTRACT)*. THESIS. CAMPINAS, 2004.}

\author{
MANOEL BALDOINO LEAL FILHO**
}

This study reports an experience with 58 Wistar adult rats who sustained acute midthoracic spine cord injury due to Fogarty's balloon-compression technique. This experience was approved by the institutional animal care and use committee (CEEA-IB-Unicamp).

In the first step all the animals, sham and experimentals, were anesthetized with intraperitoneal pentobarbital $60 \mathrm{mg} / \mathrm{Kg}$. The catheter was inserted into dorsal epidural space through a small hole made in the ligamentum flavum, advanced cranially to midthoracic spinal level, and inflated with 20 microlitres of saline only in the experimental group. The present study was performed to investigate the relationship between the spine cord injury and the time of compression $(5,15,30$ or 60 seconds). Quantitative neurological outcome was presented with 4, 24 and 48 hours from the compression to characterize the graduation of injury in different groups. The poor outcome occured with 60 seconds compression independentely of the time of neurological examination. Some animals died suddenly with pulmonary edema and a second step investigation was done to elucidate it. The aim of this second study was to show a model of neurogenic pulmonary edema due to thoracic spine injury using a Fogarty's balloon containing 20 microlitres of saline during 60 seconds of compression $(n=17)$. There were used two different group of anesthesics to compare the influence of the drugs on the pulmonary edema and three groups were constituted: sham (1), compression / pentobarbital, $60 \mathrm{mg} / \mathrm{Kg}$ (2) and compression / xylasin, 10 $\mathrm{mg} / \mathrm{Kg} / \mathrm{ketamin}, 75 \mathrm{mg} / \mathrm{Kg}$ (3).

The results indicated that there were differences between the groups. In rats with pentobarbital anesthesia systolic blood pressure doubled the baseline value during compression, whereas this effect was less pronounced in the xylasine/ketamine group. The pulmonary index (100 x wet lung weight / bodyweight) was $0.395 \pm$ 0.018 in sham (1), rose to $0.499 \pm 0.060$ in (3), and was maximum under group $2(0.639 \pm 0.14 ; p=0.0018)$. Histologic examination of the spinal cord showed parenchymal ruptures and acute hemorrhage. Comparison of the pulmonary index with morphometric evaluation of edema fluid-filled alveoli by light microscopy in paraffin sections, showed that relevant intra-alveolar edema occured only for index values above $\mathbf{0 . 5 5}$. On electron microscopy, endothelial alterations, and signs of damage of the alveolar lining cells were found.

The present study showed that the anesthesic drug pentobarbital was very important for the formation of the lung edema. The present experience suggests that the pulmonary edema induced by spinal compression is of neurogenic nature, that the anesthesic drug used had an important participation in the genesis of edema and that it is a good method to produce neurogenic pulmonary edema.

KEY WORDS: spinal cord injury, trauma, neurogenic lung edema.

*Contribuição ao estudo das alterações da medula espinhal em modelo experimental de lesão traumática na fase aguda (Resumo). Tese de Doutorado. Universidade Estadual de Campinas, UNICAMP (Área de Ciências Médicas, Neurologia). Orientador: Antonio Guilherme Borges Neto.

**Address: Rua Thomaz Tajra 1222 / 300 - 64048-380 Teresina Pl, Brasil. E-mail: manoelbaldoino@uol.com.br

\section{CORRELATION ANATOMICAL-BEHAVIOR-FARMACOLOGY OF THE PARAMETERS OF EXPERIMENTAL ANIMAL CHRONIC NEUROPATHIC PAIN (ABSTRACT)*. THESIS. FORTALEZA, 2004}

\section{NILZA DUTRA ALVES**}

Pain is a very common symptom in patients. It may involve somatic, visceral and neural structures. Neuropathic pain may be chronic with undefined mechanism and that is a challenge for therapy. With the aim of contributing to understand mechanisms and rational therapy for chronic neuropathic pain, we developed this study in order to do an anatomo-pharmacological-behavioral correlation (1) by quantifying spontaneous and induced behaviors, (2) administrating drugs with action on the GABA system, $\mathrm{Ca}++$ and $\mathrm{Na}+$ channels and (3) stimulating and inhibiting the periaqueductal region (PAG).

For this, 75 Wistar male and female rats, divided into 10 groups, were used. As model of neuropathic pain, the constriction of sciatic nerve was used. The rats were observed during 30 days and, at the 31st day, drugs were administered. For stimulation and inhibition of the PAG, a cannula was inserted in it (Groups VII, IX and X of rats). The spontaneous behaviors were observed in open field and thermal tests were carried out to induce pain behaviors. The pharmacological tests with gabapentin, vigabatrin, lamotrigin and morphine were carried out in Groups IV to VII. The stimulation with morphine and inhibition with morphine/naloxone and lidocain in the PAG were carried out in Groups VIII, IX and X of rats. 
The results showed that gabapentin, vigabatrin, lamotrigin and morphine decreased significantly the scratching and biting behaviors, as well as reverted allodynia and hyperalgesia. In addition, morphine administered in PAG reduced significantly the scratching and biting behaviors, and this effect was reverted by naloxone. Lidocaine, in its side, did not change the increased scratching and biting behaviors.

Our results may conclude that the behaviors sugges- tive of chronic neuropathic pain (scratching and biting) are inhibited by drugs with gabaergic action, blocking e ffect on $\mathrm{Ca}++$ and $\mathrm{Na}+$ channels and through PAG stimulation with morphine, as well as PAG inhibition with morphine/naloxone and lidocain. These results reinforce the interpretation of these behaviors as suggestive symptoms of chronic neuropathic pain.

KEY WORDS: pain, neuropathic chronic pain, experimental, PAG.

*Correlação anatômica-comportamental-farmacológica dos parâmetros de dor neuropática crônica experimental animal (Resumo). Tese de Dotourado, Universidade Federal do Ceará (Área: Farmacologia). Orientador: Carlos Mauricio Castro Costa.

**Address: Laboratory of Experimental Neurology (Departament of Physiology and Pharmacology), Federal University of Ceará (UFC), Rua Cel. Nunes de Melo 1127 - 60430-270 Fortaleza CE - Brasil. FAX: 558532439333.

\title{
STUDY OF MAGNETIC RESONANCE OF 1,0 T AS A METHOD OF IMAGING IN VIVO OF THE EXPERI- MENTAL HYDROCEPHALUS: ON THE APPLICATION OF THE METHOD TO EVALUATE THE SIZE OF THE VENTRICLES IN RATS SUBMITTED TO VENTRICULAR SHUNTS (ABSTRACT)*. THESIS. RIBEIRÃO PRE- TO, 2003.
}

\section{SAMUEL CAPUTO DE CASTRO**}

Magnetic resonance imaging (MRI) equipments of high field, dedicated specifically to experimental uses, have been used to study the hydrocephalus in vivo of small rats carriers of congenital hydrocephalus. In this experiment the MRI of 1,0 T (the same used to investigate neurological diseases in humans is evaluated as an imaging method to study in vivo the size of the ventricles of hydrocephalic rats of the race Wistar.

To accomplish this study, 33 rats had become hydrocephalic through the intracisternal injection of caulim. The parameters, Ventricular Ratio, Cortical Thickness and Ventricular Area, were measured at the digital picture of the MRI slice and at the anatomical slice of the brain. At eye vision, the quality of the images were sufficient to distinguish the ventricular cavities from the brain.

The ventricular ratio was the most confidant parameter to compare, resulting in a correlation ratio of 0.95 . The MRI overestimated the ventricular area in an average of $36.23 \%$. The imaging method was applied to eval- uate the size of ventricles of hydrocephalic rats submitted to a surgical ventricular shunt.

Beforehand, in order to determine the best surgical procedure, 14 hydrocephalic rats were submitted to ventricle-subcutaneous shunts, 9 to ventricle-peritoneal shunts and 6 to ventricle-pleural shunts. The ventricular-subcutaneous shunt to the neck demonstrated to be the best surgical procedure to treat the hydrocephalus in this model, because it was technically easier, faster to perform, presented less complications and has been more secure than the others to check up the patency of the system.

In another group of 26 hydrocephalic rats, the shunts to the subcutaneous tissue of the neck were more efficient to reduce the size of the ventricles when performed in animals injected, operated upon and were sacrificed much earlier than the ones injected, operated upon and sacrificed late.

KEY WORDS: experimental hydrocephalus, magnetic resonance, experimental surgery.

\footnotetext{
*Avaliação da ressonância magnética de 1,0 T como método de imagem in vivo da hidrocefalia experimental: aplicação do método na avaliação do tamanho dos ventrículos em ratos submetidos à derivação liquórica (Resumo). Tese de Doutorado, Universidade de São Paulo (Área: Cirurgia). Orientador: Hélio Rubens Machado.
}

**Address: Avenida Belo Horizonte 937 - 38400-454 Uberlândia MG - Brasil.

\begin{abstract}
THE VALUE OF THE THREE-DIMENSIONAL ANGIOTOMOGRAPHY IN DIAGNOSIS FROM THE INTRACRANIAL ANEURYSMS, WHEN COMPARED AT THE STANDARD METHOD ( DIGITAL SUBTRACTION ANGIOGRAPHY ): SYSTEMATIC REVIEW (ABSTRACT)*. DISSERTATION. SÃO PAULO, 2004.
\end{abstract}

\section{GUILHERME CABRAL DE ANDRADE**}

To evaluate the sensitivity and specificity of tridimensional computerized tomography angiography (3DCTA) in the detection of intracranial aneurysms, correlating with the digital subtraction angiography (DSA) and to determine the smaller size of the intracranial aneurysms diagnosed with the 3DTCA. The tridimensional computerized tomography angiography has utilized on the intracranial aneurysms diagnosis. 